\title{
Serotonin-induced stimulation of progesterone production by cow luteal cells in vitro
}

\author{
P. J. Battista and W. A. Condon \\ Department of Animal and Nutritional Sciences, The University of New Hampshire, Durham, \\ New Hampshire, 03824, U.S.A.
}

\begin{abstract}
Summary. The addition of acetylcholine or histamine $\left(10^{-7}\right.$ to $\left.10^{-4} \mathrm{M}\right), \gamma$-aminobutyric acid, a dopamine agonist, and melatonin $\left(10^{-7}\right.$ to $\left.10^{-5} \mathrm{M}\right)$ did not alter basal or LH-stimulated progesterone production $(P>0.05)$. The addition of the specific $\beta_{2}$-adrenergic agonist terbutaline and salbutamol did not significantly elevate progesterone production. Treatment of luteal cells with serotonin (5-HT), $10^{-6}$ to $10^{-4} \mathrm{M}$, increased the production of progesterone $(P<0.05)$. This stimulated production was inhibited by the addition of mianserin $\left(10^{-5} \mathrm{M}\right.$, a $5-\mathrm{HT}$ antagonist; $\left.P<0.05\right)$. Isoproterenol $\left(10^{-7}\right.$ to $\left.10^{-4} \mathrm{M}\right)$ also resulted in significant increases in progesterone production $(P<0 \cdot 05)$. The combined treatments of $5-\mathrm{HT}+\mathrm{LH}$, isoproterenol $+\mathrm{LH}$, or isoproterenol $+5-\mathrm{HT}$ did not result in a further increase in progesterone above that observed in response to $\mathrm{LH}$ or isoproterenol alone $(P>0.05)$. The isoproterenolinduced progesterone production could not be blocked by butoxamine $\left(10^{-5} \mathrm{M}\right.$, a $\beta_{2}$-antagonist), or practolol $\left(10^{-5} \mathrm{M}\right.$, a $\beta_{1}$-antagonist), but was inhibited by propranolol $\left(10^{-5} \mathrm{M}\right.$, a general $\beta$-antagonist; $\left.P<0 \cdot 05\right)$. The response to isoproterenol was unaffected by mianserin $\left(10^{-5} \mathrm{M}\right)$. These results demonstrate a possible role for $5-\mathrm{HT}$ in the regulation of steroidogenesis by the corpus luteum of the cow. Furthermore, these results suggest that serotonin-induced progesterone production is a receptor-mediated event.
\end{abstract}

\section{Introduction}

At the level of the ovary, the adrenergic agents adrenaline, noradrenaline and isoproterenol have been shown to stimulate cAMP and progesterone production by luteal tissue from the cow (Condon \& Black, 1976; Godkin, Black \& Duby, 1977; Milvae, Alila \& Hansel, 1983), rat (Hartwood, Richert, Dufau \& Catt, 1980; Ratner, Sanborn \& Weiss, 1980a; Norjavaara, Selstam \& Ahren, 1982), rabbit (Birnbaumer, Yang, Hunzicker-Dunn, Brockaert \& Duran, 1976), and ewe (Jordan, Caffrey \& Niswender, 1978). In contrast to the stimulatory effects of catecholamines in the aforementioned species, corpora lutea of the mare (Condon, Ganjam \& Kenney, 1979) and women (Richardson \& Masson, 1980; Casper \& Cotterell, 1984) appear to be refractory to stimulation by exogenous adrenergic agonists.

Catecholamines act directly on luteal cells, since fibroblasts and erythrocytes separated from ewe luteal cell suspensions did not produce significant amounts of cAMP in response to adrenaline (Jordan et al., 1978). Adrenergic agents are thought to induce cAMP and subsequent progesterone production by binding to specific receptors in the luteal cell membrane (Lefkowitz, 1976). Initial support for this hypothesis is suggested by the finding that propranolol can block the catecholamine-induced increase in luteal cAMP and progesterone production in the cow (Condon \& Black, 1976; Godkin et al., 1977), rat (Hartwood et al., 1980; Norjavaara et al., 1982) and ewe (Jordan et al., 1978). These results not only suggest specific adrenergic receptors, but also that they are of the $\beta$-adrenergic type. In the rat the $\beta$-adrenergic stimulation of ovarian cAMP and 
progesterone has been shown to be mediated by $\beta_{2}$-adrenergic receptors (Coleman, Paterson $\&$ Somerville, 1979a, b; Ratner, Weiss \& Sanborn, 1980b; Adashi \& Hsueh, 1981; Norjavaara, Rosberg, Gafvels \& Selstam, 1984). In the cow and ewe the characterization of a specific $\beta_{2}$-adrenergic mediation of catecholamine response by luteal cells has not been established. The purpose of this study with cow luteal cells was to determine (a) whether the catecholamine induced increase in progesterone production is mediated by a $\beta_{2}$-adrenergic receptor and (b) the role of other biogenic amines on basal and LH-stimulated progesterone production.

\section{Materials and Methods}

\section{Materials and drug preparation}

Serotonin (5-hydroxytryptamine oxalate salt; 5-HT), DL-isoproterenol $\mathrm{HCl}$, acetylcholine chloride, histamine dihydrochloride, salbutamol, $\gamma$-amino- $n$-butyric acid (GABA), melatonin ( $N$-acetyl-5-methoxytryptamine) and DL-propranolol $\mathrm{HCl}$ were purchased from Sigma Chemical Co., St Louis, MO. Mianserin $\mathrm{HCl}$ and 2-amino-6,7-dihydroxy-1,2,3,4-tetrahydronaphthalene hydrobromide were from Research Biochemicals, Inc., Wayland, $\mathrm{MA}$, and butoxamine $\mathrm{HCl}$ was from Burrough's Wellcome Co., Research Triangle Park, NC. Terbutaline was donated by Ciba-Geigy Corp., Summit, NJ. Practolol was donated by Imperial Chemical Industries PLC, Macclesfield, Cheshire, U.K. Luteinizing hormone (LH) was kindly supplied by the National Institutes of Health (NIAMMD-bLH-4). Ham's F12 culture medium was purchased from Grand Island Biological Co., Grand Island, NY. The collagenase was Worthington, Type 1, Freehold, $\mathrm{NJ}$, and the $\mathrm{N}$-2-hydroxyethylpiperazine- $\mathrm{N}$-2-ethanesulphonic acid (Hepes) was purchased from Calbiochem-Behring, San Diego, CA.

Salbutamol and terbutaline are specific $\beta_{2}$-adrenergic receptor agonists, while isoproterenol is a nonspecific $\beta$-agonist, activating both subtypes of $\beta$-receptors. Butoxamine is a specific $\beta_{2}$-adrenergic receptor antagonist and practolol a specific $\beta_{1}$-antagonist; propranolol is a nonspecific $\beta$-adrenergic blocking agent. Mianserin is a nonspecific serotonin receptor antagonist which blocks both 5-HT 1 and 5-HT $\mathrm{HT}_{2}$ receptor subtypes and 2-amino-6,7-dihydroxy1,2,3,4-tetrahydronaphthalene hydrobromide is a nonspecific dopamine agonist. All hormone and drug preparations were prepared in cold $0.05 \mathrm{M}$-phosphate-buffered saline $(\mathrm{pH} 7.4)$ before use in each experiment and used at a final concentration of $10^{-7}$ to $10^{-4} \mathrm{M}$. In all cases $\mathrm{N}$ equals the number of animals tested. Duplicate determinations of all treatments were performed for each corpus luteum.

\section{Experimental procedures}

Corpora lutea (CL) were obtained per vaginam from regularly cycling, nonlactating dairy cows on Days 10-12 of the oestrous cycle (oestrus = Day 0). The luteal tissue was placed into Ham's F12 culture medium containing $24 \mathrm{~mm}-$ Hepes $\left(\mathrm{pH} \mathrm{7.4)}\right.$ at $4^{\circ} \mathrm{C}$ for transport back to the laboratory. The luteal tissue was dissociated using collagenase (2000 U/g tissue) as described by Simmons, Caffrey, Phillips, Abel \& Niswender (1976) and modified by Pate \& Condon (1982). Cell viability was determined by the trypan blue exclusion method (Tennant, 1964). Incubations were conducted utilizing $2.5 \times 10^{5}$ viable cells/culture tube in a final volume of $1 \mathrm{ml} \mathrm{Ham}$ 's F12 culture medium. Luteal cell suspensions were incubated in a Dubnoff metabolic shaker water bath at $37^{\circ} \mathrm{C}$ starting with a 15 -min preincubation period, after which the cells were centrifuged $\left(800 \mathrm{~g}, 10 \mathrm{~min}\right.$ at $\left.4^{\circ} \mathrm{C}\right)$ and the medium discarded. The cells were then resuspended in fresh medium and the appropriate treatment solutions added. After the incubation period of $2 \mathrm{~h}$, cell suspensions were centrifuged and the culture medium was collected and stored $\left(-20^{\circ} \mathrm{C}\right)$ for subsequent determination of progesterone concentration. 
Progesterone present in the culture medium was quantitated by radioimmunoassay of unextracted samples using antiprogesterone-11-bovine serum albumin (No. 337, Niswender). This antiserum does not cross-react significantly with any other steroid present in the culture medium (Gibori, Antczak \& Rothchild, 1977). The progesterone tracer used was $\left[1,2-{ }^{3} \mathrm{H}\right]$ progesterone and was purchased from New England Nuclear (Boston, MA). The sensitivity of the assay, as determined by the lower $95 \%$ confidence limit of the maximum binding in the absence of any unlabelled progesterone, was $0.1 \mathrm{ng} / \mathrm{ml}$ medium. The intra-assay and interassay coefficients of variability were $5 \cdot 3 \%$ and $13 \cdot 3 \%$ respectively. All standards were assayed in quadruplicate, and all unknowns were assayed in duplicate.

\section{Statistical analysis}

Analysis of differences between treatment means was conducted using one-way analysis of variance followed by the Student-Newman-Keuls mean separation procedure.

\section{Results}

The effects of some of the biogenic amines on basal progesterone production are presented in Table 1. Progesterone production was not affected significantly by acetylcholine, histamine, GABA, dopamine or melatonin over the treatment concentrations tested. Similarly, none of these compounds had any effect on LH-stimulated progesterone production $(P>0.05$, Table 2$)$. Terbutaline and salbutamol did not affect the basal or LH-stimulated production of progesterone. LH (100 ng) alone resulted in a large increase in progesterone production $(P<0.01)$.

The addition of serotonin at concentrations from $10^{-6}$ to $10^{-4} \mathrm{M}$ resulted in a dose-dependent stimulation of progesterone production by the luteal cells $(P<0.05$; Fig. 1). Additionally, the 5-HT-induced progesterone response could be blocked by the addition of mianserin $\left(10^{-5} \mathrm{M}\right.$, $P<0.05$ ). The 5-HT stimulation of progesterone production was significantly less than that observed for LH alone and there was no additive effect of 5-HT combined with LH. Isoproterenol at concentrations from $10^{-7}$ to $10^{-4} \mathrm{M}$ also resulted in stimulation of progesterone production $\left(P<0.05\right.$; Fig. 2). The combination of isoproterenol plus LH or isoproterenol plus 5-HT $\left(10^{-5} \mathrm{M}\right)$ did not result in a significant elevation of progesterone above that observed with $\mathrm{LH}$ or

Table 1. Effect of biogenic amines on progesterone production $(\mathrm{ng} / \mathrm{ml}$ culture medium) by dissociated luteal cells in a $2-\mathrm{h}$ incubation

\begin{tabular}{|c|c|c|c|c|c|c|}
\hline \multirow[b]{2}{*}{ Treatment } & \multirow[b]{2}{*}{$\mathrm{N}$} & \multicolumn{5}{|c|}{ Treatment concentration } \\
\hline & & 0 & $10^{-4} M$ & $10^{-5} \mathrm{M}$ & $10^{-6} \mathrm{M}$ & $10^{-7} \mathrm{M}$ \\
\hline Control & 14 & $42 \cdot 6 \pm 3 \cdot 22$ & & & & \\
\hline LH & 14 & $188 \cdot 3 \pm 14.94^{*}$ & & & & \\
\hline Acetylcholine & $(\mathrm{N})$ & & $57 \cdot 3 \pm 6 \cdot 26(5)$ & $51 \cdot 5 \pm 5.04(8)$ & $59.1 \pm 7.28(8)$ & $57 \cdot 1 \pm 4 \cdot 73(7)$ \\
\hline Histamine & 4 & & $61.7 \pm 13.67$ & $46.9 \pm 8.98$ & $44 \cdot 1 \pm 6 \cdot 80$ & $44.2 \pm 5.90$ \\
\hline$\gamma$-Aminobutyric acid & 4 & & & $45.5 \pm 4.90$ & $53.0 \pm 13.03$ & $47.8 \pm 10.86$ \\
\hline Dopamine agonist & 4 & & & $47.6 \pm 3.65$ & $43.4 \pm 6.62$ & $44.8 \pm 8.07$ \\
\hline Melatonin & 4 & & & $54.9 \pm 7.92$ & $54.5 \pm 4.76$ & $43 \cdot 6 \pm 4 \cdot 19$ \\
\hline Terbutaline & 3 & & $65 \cdot 3 \pm 8 \cdot 20$ & $58 \cdot 8 \pm 16 \cdot 49$ & $53.6 \pm 7.61$ & $41 \cdot 5 \pm 9 \cdot 38$ \\
\hline Salbutamol & 6 & & $69.4 \pm 5.66$ & $61 \cdot 7 \pm 5.53$ & $63.8 \pm 4.41$ & $49 \cdot 7 \pm 3 \cdot 28$ \\
\hline
\end{tabular}

Values are mean \pm s.e.m.

* $P<0.01$ compared with control value. 
Table 2. Effect of biogenic amines on LH-stimulated progesterone production ( $\mathrm{ng} / \mathrm{ml}$ culture medium) by dissociated luteal cells in a 2 -h incubation

\begin{tabular}{lcccccc}
\hline \multicolumn{5}{c}{} & \multicolumn{5}{c}{ Treatment concentration } \\
\cline { 3 - 7 } Treatment & $\mathrm{N}$ & 0 & $10^{-4} \mathrm{M}$ & $10^{-5} \mathrm{M}$ & $10^{-6} \mathrm{M}$ & $10^{-7} \mathrm{M}$ \\
\hline Control & 14 & $42 \cdot 6 \pm 3 \cdot 22$ & & & & \\
LH & 14 & $188 \cdot 3 \pm 14 \cdot 94^{*}$ & & & & \\
Acetylcholine & $(\mathrm{N})$ & & $191 \cdot 1 \pm 36 \cdot 96(4)$ & $211 \cdot 1 \pm 27 \cdot 64(6)$ & $221 \cdot 1 \pm 29 \cdot 99(6)$ & $197 \cdot 1 \pm 26 \cdot 08(6)$ \\
Histamine & 3 & & $156 \cdot 0 \pm 24 \cdot 29$ & $149 \cdot 2 \pm 21 \cdot 24$ & $153 \cdot 4 \pm 22 \cdot 59$ & $149 \cdot 6 \pm 25 \cdot 19$ \\
$\gamma$-Aminobutyric acid & 3 & & & $168 \cdot 4 \pm 11 \cdot 85$ & $176 \cdot 6 \pm 13 \cdot 96$ & $214 \cdot 8 \pm 20 \cdot 03$ \\
Dopamine agonist & 3 & & & $198 \cdot 6 \pm 45 \cdot 88$ & $188 \cdot 8 \pm 46 \cdot 01$ & $179 \cdot 9 \pm 42 \cdot 02$ \\
Melatonin & 3 & & & $212 \cdot 7 \pm 10 \cdot 25$ & $216 \cdot 1 \pm 9 \cdot 00$ & $212 \cdot 2 \pm 17 \cdot 16$ \\
Terbutaline & 3 & & $186 \cdot 6 \pm 18 \cdot 76$ & $162 \cdot 8 \pm 27 \cdot 04$ & $148 \cdot 1 \pm 31 \cdot 05$ & $140 \cdot 3 \pm 24 \cdot 11$ \\
Salbutamol & 3 & & $200 \cdot 6 \pm 51 \cdot 96$ & $203 \cdot 8 \pm 36 \cdot 28$ & $202 \cdot 5 \pm 48 \cdot 06$ & $197 \cdot 7 \pm 26 \cdot 06$ \\
\hline
\end{tabular}

Values are mean \pm s.e.m.

$* P<0.01$ compared with control value.

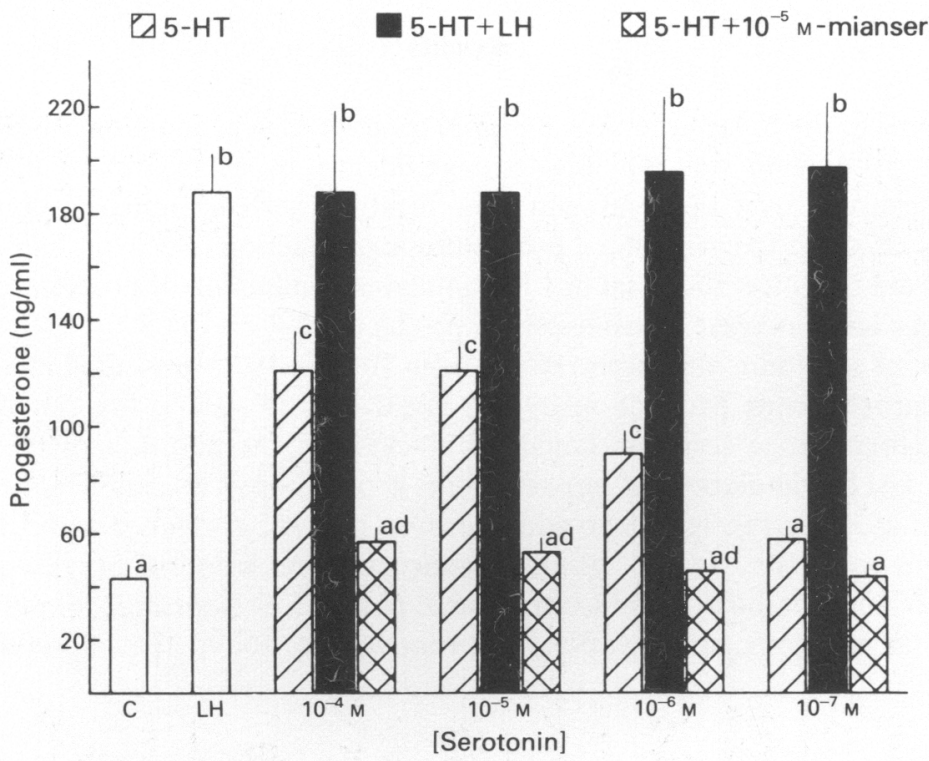

Fig. 1. Effect of serotonin on progesterone production by dissociated luteal cells. Data are expressed as mean \pm s.e.m. with $\mathrm{N}=6\left(10^{-4} \mathrm{M}\right)$ and $8\left(10^{-7}, 10^{-6}\right.$ and $\left.10^{-5} \mathrm{M}\right)$ for 5-HT, $\mathrm{N}=3$ for $5-\mathrm{HT}+\mathrm{LH}, \mathrm{N}=6$ for $5-\mathrm{HT}+$ mianserin and $\mathrm{N}=14$ for control (C) and LH. Bars with different superscript letters are significantly different $(P<0 \cdot 01, \mathrm{LH}$ and $5-\mathrm{HT}+\mathrm{LH}$; $P<0 \cdot 05,5-\mathrm{HT}$ and 5-HT + mianserin).

isoproterenol, respectively $(P>0.05)$. The effect of various $\beta$-adrenergic receptor antagonists and mianserin upon isoproterenol-stimulated progesterone is presented in Fig. 3 . The isoproterenol-induced response could not be inhibited by butoxamine $\left(10^{-5} \mathrm{M}\right)$ or practolol $\left(10^{-5} \mathrm{M}\right)$ at any of the isoproterenol concentrations tested $(P>0.05)$. Similarly, mianserin $\left(10^{-5} \mathrm{M}\right)$ did not block progesterone production by isoproterenol $(P>0.05)$. In contrast, propranolol $\left(10^{-5} \mathrm{M}\right)$ did inhibit the isoproterenol-induced response at an isoproterenol concentration of $10^{-7}$ to $10^{-5} \mathrm{M}(P<0.05)$. None of the antagonists used in these studies significantly affected basal or LH-stimulated progesterone production (data not shown). 


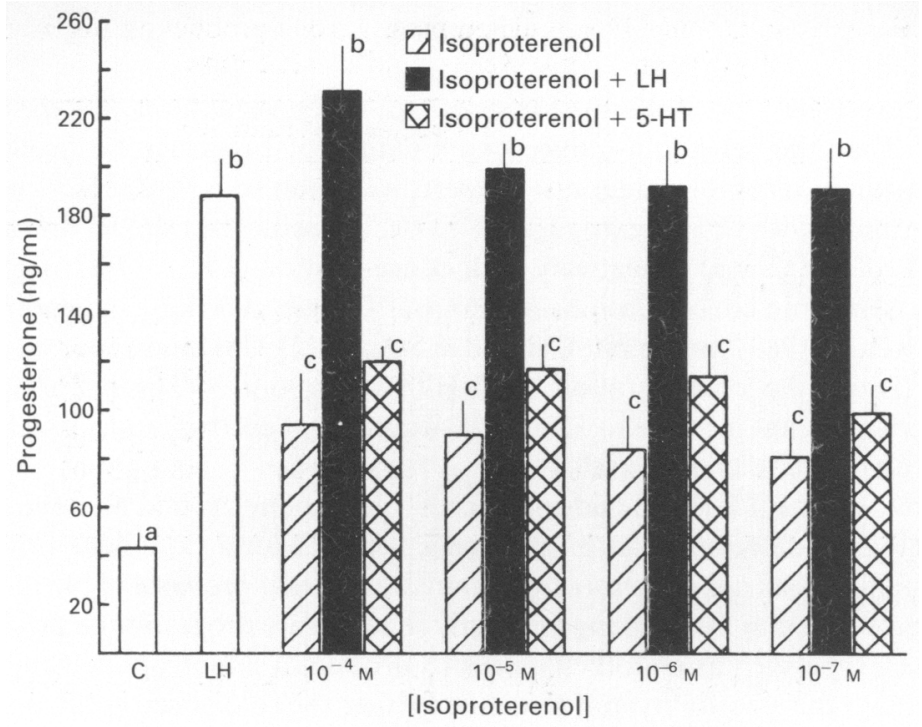

Fig. 2. Effect of isoproterenol on luteal cell progesterone production. Data are expressed as mean \pm s.e.m. with $\mathrm{N}=5\left(10^{-4} \mathrm{M}\right)$ and $6\left(10^{-7}, 10^{-6}\right.$ and $\left.10^{-5} \mathrm{M}\right)$ for isoproterenol, $\mathrm{N}=3$ for isoproterenol $+\mathrm{LH}$ and isoproterenol $+5-\mathrm{HT}$, and $\mathrm{N}=14$ for control $(\mathrm{C})$ and $\mathrm{LH}$. Bars with different superscript letters are significantly different $(P<0 \cdot 01, \mathrm{LH}$ and isoproterenol $+\mathrm{LH}$; $P<0.05$ for isoproterenol and isoproterenol $+5-\mathrm{HT})$.

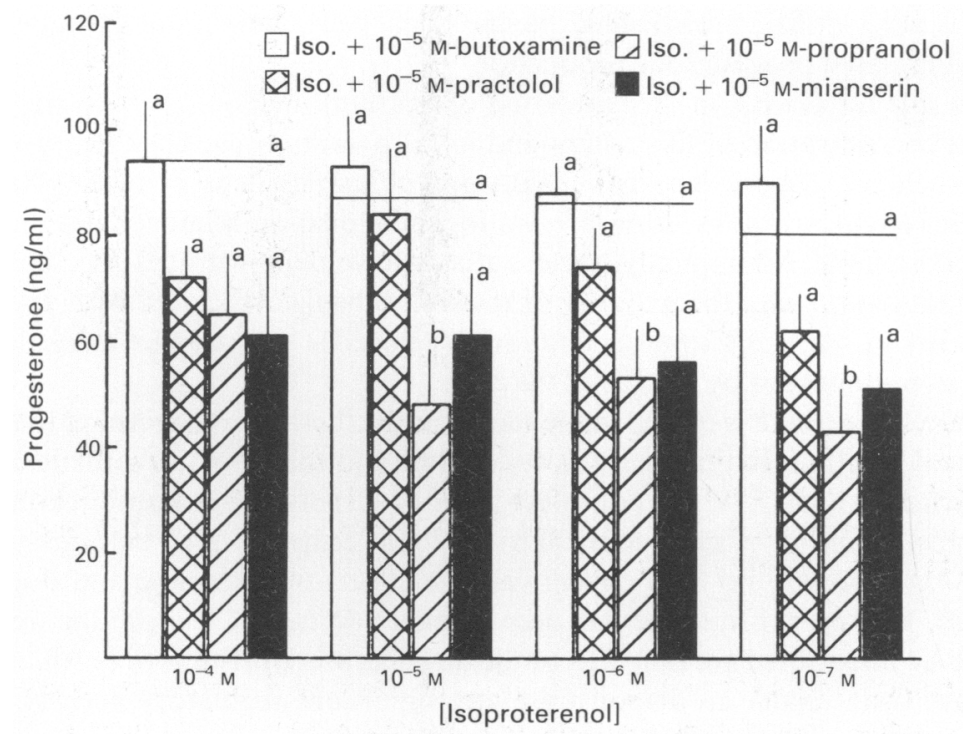

Fig. 3. Effect of $\beta$-adrenergic antagonists and mianserin on isoproterenol-stimulated progesterone production. Data are expressed as mean \pm s.e.m. with $\mathrm{N}=4$ for isoproterenol (Iso.) + butoxamine and isoproterenol + mianserin, $\mathrm{N}=3$ for isoproterenol + practolol and isoproterenol+propranolol and $\mathrm{N}=14$ for control (C) and LH. Bars with different superscript letters are significantly different from isoproterenol alone $(-)(P<0 \cdot 05$, for isoproterenol + propranolol). 


\section{Discussion}

These results demonstrate a possible role for serotonin in the regulation of steroidogenesis by the $\mathrm{CL}$ of the cow. That the serotonin-induced stimulation of progesterone production could be inhibited by a serotonin receptor antagonist suggests its action to be a receptor-mediated event. A preliminary experiment with C. E. Rexroad, Jr (USDA, Beltsville) has shown that serotonin is present within the CL of the cow at a relatively high concentration $(152 \cdot 7 \pm 40 \cdot 19 \mathrm{ng} / \mathrm{g})$. In the pineal gland of the cow, serotonin concentrations range from 1000 to $2000 \mathrm{ng} / \mathrm{g}$ depending upon the time of year (Philo \& Reiter, 1980). In the rat, Clausell \& Soliman (1978) have reported 5-HT to be present in ovarian tissue: the concentration of $5-\mathrm{HT}$ was about $900 \mathrm{ng} / \mathrm{g}$ during dioestrus and metoestrus with a significant increase to $1300 \mathrm{ng} / \mathrm{g}$ occurring at oestrus, and a role for ovarian 5-HT in the process of ovulation was proposed.

Possible sources of luteal 5-HT include mast cells, blood platelets and de-novo synthesis. In this laboratory, histological determination of mast cells using Giemsa, toluidene blue and methylene blue staining techniques has not conclusively demonstrated their presence in luteal tissue of cows. It is possible that serotonin may be working indirectly to stimulate progesterone production by acting on a secondary cell type such as endothelial cells to produce a luteotrophin. Studies are presently underway to evaluate this possibility and to define further the role of serotonin and its metabolites in the regulation of steroidogenesis by the bovine $\mathrm{CL}$.

In-vitro studies with human CL slices showed that melatonin stimulated progesterone production in a dose-dependent manner while serotonin and $\mathrm{N}$-acetyl serotonin had no effect on progesterone production (MacPhee, Cole \& Rice, 1975). In cultured rat granulosa cells, melatonin has been reported to increase basal and LH-stimulated progesterone production (Fiske, Parker, Ulmer, Ow \& Aziz, 1984). [ $\left.{ }^{3} \mathrm{H}\right]$ Melatonin has been reported to be selectively taken up by the ovaries in the rat and cat in vivo (Wurtman, Axelrod \& Potter, 1964). In male rats melatonin and serotonin have been demonstrated to inhibit the in-vitro biosynthesis of androgens (Peat \& Kinson, 1971; Ellis, 1972). In our studies utilizing dissociated bovine luteal cells, melatonin was unable to alter either basal or LH-stimulated progesterone production.

A possible role for GABA in the regulation of ovarian function has been suggested due to the relatively high concentration of this compound in rat ovarian tissue (Del Rio \& Caballero, 1980). Shaeffer \& Hsueh (1982) have reported GABA and glutamate decarboxylase (GAD), the enzyme responsible for GABA synthesis, to be present in whole ovarian homogenates but not in enriched ovarian granulosa cells. Additionally, these authors have demonstrated specific binding sites for GABA in the rat ovary, with the majority of these sites being associated with granulosa cells. The testing of GABA in our short-term incubation system does not support a role for GABA in the regulation of steroidogenesis by the $\mathrm{CL}$ of the cow.

To our knowledge, there is only a single report in the literature concerning the effects of acetylcholine on luteal function. In that study, acetylcholine and cabachol (a synthetic cholinergic agent) at concentrations up to $10^{-4} \mathrm{M}$ did not affect basal or $\mathrm{LH}$-stimulated production of progesterone by human luteal tissue in a short-term $(4 \mathrm{~h})$ or long-term (10 day) culture system (Casper \& Cotterell, 1984). There are no data concerning the effects of histamine and dopamine on luteal steroidogenesis. However, histamine has been reported to induce the production of cortisol and corticosterone by dissociated adrenal cells of the dog (Hirose, Matsumoto \& Aikawa, 1978). In our studies we have been unable to demonstrate any significant regulatory actions of acetylcholine, histamine or dopamine in controlling luteal steroidogenesis.

The isoproterenol stimulation of progesterone reported in this study is consistent with previous results reported for bovine luteal slices (Condon \& Black, 1976; Godkin et al., 1977) and dissociated bovine luteal cells (Milvae et al., 1983). Neither terbutaline nor salbutamol, the two $\beta_{2}$-adrenergic agonists used in the present study, significantly affected progesterone production by bovine luteal cells. These results differ from those reported for rat luteal tisue (Ratner et al., 1980b; Norjavaara et al., 1984) and FSH-primed rat granulosa cells (Adashi \& Hsueh, 1981). 
Additionally, isoproterenol was reported to stimulate cAMP by rat luteal tissue, and this response could not be blocked by a $\beta_{1}$ - or a $\beta_{2}$-adrenergic receptor antagonist, although it could be blocked by propranolol (Ratner et al., 1980b). Similar results have been found in this study for progesterone production by bovine luteal cells. The isoproterenol stimulation of progesterone production could not be blocked by butoxamine or practolol, but was inhibited by propranolol. The effects of isoproterenol, either alone or in combination with these antagonists, on progesterone production by rat luteal tissue was not reported by Ratner et al. (1980b). It may be that the $\beta$-adrenergic agonists and antagonists used in these studies lack the specificity and affinity for $\beta$-adrenergic receptors on bovine luteal cell membranes. In the rat, salbutamol and terbutaline have been shown to be partial agonists and their affinity varies between tissue types (Coleman et al., 1979a, b; Adashi \& Hsueh, 1981; Laszlovszky \& Erdo, 1983; Norjavaara et al., 1984). As suggested by Coleman et al. $(1979 \mathrm{~b})$ it is also possible that these $\beta$-adrenergic agonists and antagonists are metabolized more readily than isoproterenol or propranolol, thus reducing their biological activity. Since neither $\beta_{1^{-}}$nor $\beta_{2}$-adrenergic antagonists blocked the isoproterenol stimulation of progesterone but propranolol, an adrenergic antagonist which blocks both receptor subtypes, was able to, these results may suggest a mixed population of $\beta$-adrenergic receptors on luteal cells of the cow.

Scientific Contribution Number 1348 from the New Hampshire Agricultural Experiment Station. We thank Dr G. D. Niswender for the gift of progesterone antiserum, and Dr Salvatore Raiti of the National Hormone and Pituitary Program of the NIADDK-NIH for the LH used in this study. This research was a contribution to Northeast Regional Project NE-72.

\section{References}

Adashi, E.Y. \& Hsueh, A.J.W. (1981) Stimulation of $\boldsymbol{\beta}_{2}$-adrenergic responsiveness by follicle-stimulating hormone in rat granulosa cells in vitro and in vivo. Endocrinology 108, 21 70-2178.

Birnbaumer, L., Yang, P.C., Hunzicker-Dunn, M., Brockaert, J. \& Duran, J.M. (1976) Adenyl cyclase activities in ovarian tissues. I. Homogenization and conditions of assay in Graafian follicles and corpora lutea of rabbits, rats and pigs: regulation by ATP, and some comparative properties. Endocrinology 99, $163-184$.

Casper, R.F. \& Cotterell, M.A. (1984) The effects of adrenergic and cholinergic agents on progesterone production by human corpus luteum in vitro. Am. J. Obstet. Gynecol. 148, 663-669.

Clausell, D.E. \& Soliman, K.F.A. (1978) Ovarian serotonin content in relation to ovulation. Experientia 34, 410-411.

Coleman, A.J., Paterson, D.S. \& Somerville, A.R. (1979a) The $\beta$ adrenergic receptor of rat corpus luteum membranes. Biochem. Pharmacol. 28, 1003-1010.

Coleman, A.J., Paterson, D.S. \& Somerville, A.R. $(1979 \mathrm{~b})$ Factors controlling the selectivity of $\beta$ blocking drugs. Biochem. Pharmacol. 28, 1011-1013.

Condon, W.A. \& Black, D.L. (1976) Catecholamine-induced stimulation of progesterone by the bovine corpus luteum in vitro. Biol. Reprod. 15, 573-578.

Condon, W.A., Ganjam, V.K. \& Kenney, R.M. (1979) Catecholamines and equine luteal progestagens. $J$. Reprod. Fert., Suppl. 27, 199-203.

Del Rio, R.M. \& Caballero, A.L. (1980) Presence of $\gamma$-aminobutyric acid in rat ovary. $J$. Neurochem. 34, $1584-1586$.

Ellis, L.C. (1972) Inhibition of rat testicular androgen synthesis in vitro by melatonin and serotonin. Endocrinology 90, 17-28.

Fiske, V.M., Parker, K.L., Ulmer, R.A., Ow, C.H. \& Aziz, N. (1984) Effect of melatonin alone or in combination with human chorionic gonadotropin or ovine luteinizing hormone on the in vitro secretion of estrogens or progesterone by granulosa cells of rats. Endocrinology 114, 407-410.

Gibori, G., Antczak, E. \& Rothchild, I. (1977) The role of estrogen in the regulation of luteal progesterone secretion in the rat after day 12 of pregnancy. Endocrinology 100, 1483-1495.

Godkin, J.D., Black, D.L. \& Duby, R.T. (1977) Stimulation of cyclic AMP and progesterone synthesis by $\mathrm{LH}, \mathrm{PGE}_{2}$ and isoproterenol in the bovine $\mathrm{CL}$ in vitro. Biol. Reprod. 17, 514-518.

Hartwood, J.P., Richert, N.D., Dufau, M.L. \& Catt, K.J. (1980) Gonadotropin-induced desensitization of epinephrine action in the luteinized rat ovary. Endocrinology 107, 280-288.

Hirose, T., Matsumoto, I. \& Aikawa, T. (1978) Direct effect of histamine on cortisol and corticosterone production by isolated dog adrenal cells. $J$. Endocr. 76, 371-372.

Jordan, A.W., III, Caffrey, J.L. \& Niswender, G.D. (1978) Catecholamine-induced stimulation of progesterone and adenosine $3^{\prime}, 5^{\prime}$-monophosphate production by dispersed ovine luteal cells. Endocrinology 103, 385-392. 
Laszlovszky, I. \& Erdo, S.L. (1983) Characterization of $\beta$-adrenergic receptors in rat ovary. Eur. J. Pharmacol. 96, 101-104.

Lefkowitz, R.J. (1976) $\beta$-adrenergic receptors: recognition and regulation. N. Engl. J. Med. 295, 323-328.

MacPhee, A.A., Cole, F.E. \& Rice, B.F. (1975) The effect of melatonin on steroidogenesis by the human ovary in vitro. J. clin. Endocr. Metab. 40, 688-696.

Milvae, R.A., Alila, H.W. \& Hansel, W. (1983) Methylation in bovine luteal cells as a regulator of luteinizing hormone action. Biol. Reprod. 29, 849-855.

Norjavaara, E., Selstam, G. \& Ahren, K. (1982) Catecholamine stimulation of cyclic AMP and progesterone production in rat corpora lutea of different ages. Acta endocr., Copenh. 100, 613-622.

Norjavaara, E., Rosberg, S., Gafvels, M. \& Selstam, G. (1984) $\beta$-adrenergic receptor concentration in corpora lutea of different ages obtained from pregnant mare serum gonadotropin-treated rats. Endocrinology 114, $2154-2159$.

Pate, J.L. \& Condon, W.A. (1982) Effect of serum and lipoproteins on steroidogenesis in cultured bovine luteal cells. Molec, cell. Endocr. 28, 551-562.

Peat, F. \& Kinson, G.A. (1971) Testicular steroidogenesis in vitro in the rat in response to blinding, pinealectomy and to the addition of melatonin. Steroids 17, 251-264.

Philo, R. \& Reiter, R.J. (1980) A circannual rhythm in bovine pineal serotonin. Experientia 36, 664-665.
Ratner, A., Sanborn, C.R. \& Weiss, G.K. (1980a) $\beta$-Adrenergic stimulation of cAMP and progesterone in rat ovarian tissue. Am. J. Physiol. 239, E139-E143.

Ratner, A., Weiss, G.K. \& Sanborn, C.R. (1980b) Stimulation by $\beta_{2}$-adrenergic receptors of the production of cyclic AMP and progesterone in rat ovarian tissue. J. Endocr. 87, 123-129.

Richardson, M.C. \& Masson, G.M. (1980) Progesterone production by dispersed cells from human corpus luteum: stimulation by gonadotrophins and prostaglandin $\mathrm{F}_{2} \alpha$ lack of response to adrenaline and isoprenaline. J. Endocr. 87, 247-254.

Shaeffer, J.M. \& Hsueh, A.J.W. (1982) Identification of gamma-aminobutyric acid and its binding sites in the rat ovary. Life Sci. 30, 1599-1604.

Simmons, K.R., Cafirey, J.L., Phillips, J.L., Abel, J.H., Jr \& Niswender, G.D. (1976) A simple method for preparing suspensions of luteal cells. Proc. Soc. exp. Biol. Med. 152, 366-371.

Tennant, J.R. (1964) Evaluation of the trypan blue technique for determination of cell viability. Transplantation 2, 685-694.

Wurtman, R.J., Axelrod, J. \& Potter, L.T. (1964) The uptake of $\mathbf{H}^{3}$-melatonin in endocrine and nervous tissues and the effects of constant light exposure. $J$. Pharmacol. exp. Ther. 143, 314-321.

Received 10 April 1985 